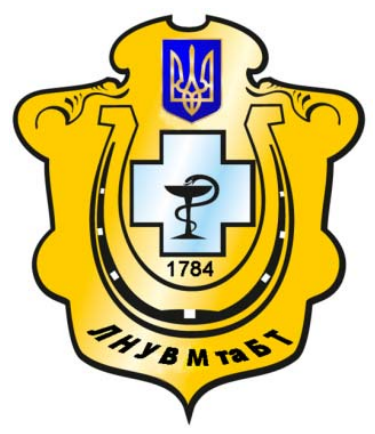

Науковий вісник Львівського національного університету ветеринарної медицини та біотехнологій імені С.3. Гжицького

Scientific Messenger of Lviv National University of Veterinary Medicine and Biotechnologies named after S.Z. Gzhytskyj

doi:10.15421/nvlvet7509

ISSN 2519-268X print

ISSN 2518-1327 online

$\underline{\text { http://nvlvet.com.ua/ }}$

УДК 637.2

\title{
Дослідження функціонально-технологічних властивостей білково-полісахаридних комплексів та їх використання у технології масляних паст
}

\author{
О.В. Яценко, Н.М. Ющенко, В.М. Пасічний \\ olgayatsenko88@gmail.com \\ Начіональний університет харчових технологій, \\ вул. Володимирська, 68, м. Киї, 01601, Україна
}

\begin{abstract}
Перспективним напрямком розвитку асортименту продуктів з підвищеним вмістом жиру є збільшення білкової складової. Авторами аргументовано доцільність використання у технології масляних паст 15,0\% розчину казеїнату натрію на основі знежиреного молока у кількості від 30,0 до 50,0\% до загальної маси продукту. Об'єкт досліджень - технологія масляних паст. Предмет досліджень - модельні розчини полісахаридів, білково-полісахаридні комплекси (БПК) на знежиреному молоці та виготовлені на їх основі зразки масляних паст з масовою часткою жиру 45,0\%. Здійснювалась оцінка органолептичних показників масляних паст, термостійкість та дисперсність плазми, дослідження реологічних властивостей розчинів за допомогою ротачійного віскозиметра «Rheotest-2». Встановлено, щяо граничне напруження на зріз для зразків із масовою часткою казейнату натрію 10,25\% перевищували відповідний показник контрольного зразка для моделей із камедями ксантана - у 8,8 разів; рожкового дерева - у 8,8 разів, гуара - у 8,5 разів. Значне підвищення показника граничного напруження на зсув у зразках із сумісним використанням казеїнату натрію та полісахаридів свідчить про ефрект функиіонального синергізму внаслідок комплексоутворення між вищезазначеними компонентами. Термостійкість дослідних зразків масляних паст після 6-ї доби набула сталих значень (в межах 0,86-0,88), ще вказує на завершення процесів формування структури. Доведено можливість створення ефективних білково-полісахаридних комплексів (БПК) шляхом поєднання казеїнату натрію та камедей гуара, ксантана і рожкового дерева. Застосування таких комплексів дозволить знизити дозу введення казеїнату натрію в середньому на 25\% та забезпечити отримання масляних паст із органолептичними та структурно-механічними показниками, наближеними до традииійного верикового масла. Зниження дози введення казеїнату натрію у складі рецептур масляних паст позитивно позначиться на собівартості продукту. Отримані результати будуть покладені в основу подальших наукових досліджень у напрямі створення БПК із залученням більш широкого спектру иільових функціонально-технологічних інгредієнтів.

Ключові слова: масляна паста, білково-полісахаридний комплекс, казеїнат натрію, структуроутворення, функиіонально-технологічний компонент.
\end{abstract}

\section{Исследование функционально-технологическиевойства белково-полисахаридных комплексов и их использования в технологии масляных паст}

\author{
О.В. Яценко, Н.М. Ющенко В.М. Пасичный \\ olgayatsenko88@gmail.com \\ Национальный университет пищевых технологий, \\ ул. Владимирская, 68, г. Киев, 01601, Украина
}

Перспективным направлением развития ассортимента продуктов с повышенным содержанием жира является увеличение белковой составляющей. Авторами аргументированно целесообразность использования в технологии масляных паст

\section{Citation:}

Yatsenko, O., Yuschenko, N., Pasichniy, V. (2017). Investigation of the functional and technological properties of the protein-polysaccharide complexes and their application in technology of butter paste. Scientific Messenger LNUVMBT named after S.Z. Gzhytskyj, 19(75), 45-49. 
15,0\% раствора казеината натрия на основе обезжиренного молока в количестве от 30,0 до 50,0\% к общей массе продукта. Объект исследований - технология масляных паст. Предмет исследований - модельные растворы полисахаридов, белково-полисахаридные комплексы (БПК) на обезжиренном молоке и изготовленные на их основе образиы масляных паст с массовой долей жира 45,0\%. Осущчествлялась оценка органолептических показателей масляных паст, определялась термостойкость и дисперсность плазмы, были исследованы реологические свойств растворов с помощью ротационного вискозиметра «Rheotest-2». Установлено, что полученные значения предельного напряжения сдвига для образиов с массовой долей казеината натрия 10,25\% превышали аналогичные значения контрольного образца для моделей с камедями ксантана - в 8,8 раз; камедью рожкового дерева - в 8,8 раз, гуара - в 8,5 раз. Значительное возрастание показателя предельного напряжения на сдвиг в образиах с совместным использованием казеината натрия и полисахаридов свидетельствует об эффекте функиионального синергизма, в результате комплексообразования между вымеупомянутыми компонентами. Термостойкость опытных образијов масляных паст после 6-го дня приобрела постоянное значение (в пределах 0,86-0,88), что указывает на завершение прочессов формирования структуры. Доказана возможность создания эффективных белково-полисахаридных комплексов путем сочетания казеината натрия и камедей гуара, ксантан и рожкового дерева. Применение таких комплексов позволит снизить дозу введения казеината натрия в среднем на 25,0\% и обеспечить получение масляных паст с органолептическими и структурно-механическими показателями, приближенными к традиционному сливочному маслу. Снижение дозы введения казеината натрия в составе речептур масляных паст позитивно отобразится на себестоимости продукта. Полученные результаты будут положены в основу создания БПК с привлечением более иирокого спектра ичелевых функиионально-технологических ингредиентов.

Ключевые слова: масляная паста, белково-полисахаридный комплекс, казеинат натрия, структурообразование, функционально-технологический компонент.

\title{
Investigation of the functional and technological properties of the protein- polysaccharide complexes and their application in technology of butter paste
}

\author{
O. Yatsenko, N. Yuschenko, V. Pasichniy \\ olgayatsenko88@gmail.com \\ National University of Food Technologies, \\ Volodymyrska Str., 68, Kyiv, 01601, Ukraine
}

The perspective direction of assortment development of products with high fat content is an increase in the protein component. The authors reasoned the expediency of using the sodium caseinate (a form of the supplement is 15.0\% solution in the skim milk). Number of food additive is from 30.0 to $50.0 \%$ of the total weight of the product. The object of research is the technology of butter pastes. The subject of the research was model solutions of polysaccharides, protein-polysaccharide complexes (PPC), which were prepared in skim milk and samples of oil pastes (fat content 45.0\%), which contained these PPC. The organoleptic parameters of oil pastes were evaluated, the heat resistance and dispersity of the plasma were determined. And the rheological properties were examined. The viscosity of the solutions with PPC-complex based on sodium caseinate was measured using a rotational viscometer «Reotest $2 \%$. It was found that the obtained values of the limiting shear stress for samples with a mass fraction of sodium caseinate $10.25 \%$ were higher than the analogous values for the control sample. These values were 8.8 times more for models with xanthan gum, were more 8.8 times for models with locust bean gum, in 8.5 times for models with guar gum. A significant increase in the stress limit for shear in samples with the combined use of sodium caseinate and polysaccharides testifies to the effect of functional synergism, as a result of complexation between the aforementioned components of this food system. The value of the heat resistance index of the test samples of butter pastes became constant after the 6th day (the value of 0.86-0.88). This indicates that the processes of structure formation in the butter paste were completed. The possibility of creating effective protein-polysaccharide complexes by combining sodium caseinate and guar gum, xanthan gum and locust bean gum is proved. That will give a real opportunity to reduce the amount of sodium caseinate application by $25.0 \%$ from the initial one and, at the same time, to obtain butter pastes with good organoleptic, structural and mechanical properties that would be similar to the traditional cream butter. Partial reduction in the amount of sodium caseinate in the formulation of butter pastes by developing PPC will have a positive effect on the cost of the product. The obtained results will be used as a basis for the creation of the PPC with the involvement of a wider range of targeted functional and technological ingredients.

Key words: butter paste, protein-polysaccharide complex, sodium caseinate, structure formation, functional-technological component butter paste, protein-polysaccharide complex, sodium caseinate, structure formation, functional-technological component.

\section{Вступ}

Одним із перспективних напрямків розвитку асортименту продуктів з підвищеним вмістом жиру є збільшення білкової складової. При цьому введений до продукту білок повинен відігравати поліфункціональну роль, і слугувати не лише збагачуючим компонентом, а й виявляти структуроутворюючу, вологоутримуючу функції та забезпечувати супрамолекулярну взаємодію фаз харчової системи.

За результатами попередніх досліджень авторами аргументовано доцільність використання у рецепту- pax масляних паст казеїнату натрію. Казеїнат натрію (КН) передбачено вводити у вигляді $15,0 \%$ розчину на основі знежиреного молока у кількості від 30,0 до $50,0 \%$ до загальної маси продукту.

Однак, хоча вищенаведена кількість КН забезпечувала задані технологічні властивості при виробництві масляних паст, проте зумовлювала виникнення у готових продуктах специфічного присмаку та запаху молочного білка. Тому виникла необхідність удосконалення компонентного складу МП у напрямку зменшення кількості казеїнату натрію. На думку ряду авторів, одним із найбільш перспективних та актуаль- 
них шляхів вирішення поставленої задачі $є$ використання здатності білків утворювати комплекси нанорозмірних структур із іонними та неіонними полісахаридами (гідроколоїдами) (Graveland-Bikker and de Kruif, 2006; Imeson, 2010; Derkach et al., 2012).

Мета досліджень. Розробка білково-вуглеводних функціонально-технологічних комплексів на основі КН. За літературними даними (Topnikova, 2006) було обрано найбільш доцільні для дослідження полісахариди, представлені на ринку України, зокрема камеді: гуарова, ксантанова, рожкового дерева. Одним із критеріїв вибору полісахаридів виступала кореляція стандартизованого показника активної кислотності вершкового масла та значень $\mathrm{pH}$ для полісахаридів, в межах яких вони здатні виявляти стабільні технологічні властивості.

Створення ефективних білково-полісахаридних комплексів (БПК) дозволить: по-перше, частково знизити дозу введення КН з метою корегування органолептичних показників масляних паст; по-друге, забезпечити максимальне наближення органолептичних показників вироблених продуктів до традиційного вершкового масла та зберегти бажані структурні характеристики масляної пасти; no-третє, раціоналізувати економічну складову рецептурного складу масляної пасти , тобто зробити продукт більш економічно привабливим.

\section{Матеріали і методи досліджень}

У якості об'єкта досліджень обрано технологію масляних паст. Предметом досліджень виступали

модельні розчини полісахаридів, БПК на знежиреному молоці та виготовлені на їх основі зразки масляних паст $з$ масовою часткою жиру 45,0\%. В якості контрольних зразків було обрано $15,0 \%$ розчин КН на знежиреному молоці, МП, виготовлена на його основі та вершкове масло, взяте в якості жирової основи. Матеріалами для досліджень виступали зразки сухого КН виробництва ТОВ «ДейріКо» (м. Луцьк, Україна) згідно ТУ У 20.5-40392270-003, молоко знежирене 3 масовою часткою жиру $0,05 \%$, білка $-3,2 \%$, отримане сепаруванням незбираного молока, що відповідає вимогам ДСТУ 3662, масло солодковершкове згідно ДСТУ 4399 з масовою часткою жиру 72,5\%. Для досліджень використовувалися наступні полісахариди: гуарова камедь (Danisco, Данія), ксантанова камідь (Danisco, Данія), камідь рожкового дерева (FMC comp., USA).

Оцінка органолептичних показників, термостійкість та дисперсність плазми проводилася за загальноприйнятими методиками. Дослідження реологічних властивостей проводилися за допомогою ротаційного віскозиметра 3 коаксіальними циліндрами «Rheotest2» (Німеччина), система $\mathrm{S} / \mathrm{H}$ в діапазоні швидкостей зсуву від 0,333 до 145,8 $\mathrm{c}^{-1}$ (Kosoj et al., 2010). Кратність повторень досліджень - три. Реологічні дослідження проводили при температурі $12 \pm 1{ }^{\circ} \mathrm{C}$.

\section{Результати та їх обговорення}

Для досліджень готувалися модельні розчини, компонентний склад яких наведено у таблиці.

Табличяя

Компонентний склад досліджуваних модельних розчинів

\begin{tabular}{|c|c|c|c|c|c|c|c|c|c|c|}
\hline \multirow{3}{*}{$\begin{array}{c}\text { Найменування } \\
\text { компоненту }\end{array}$} & \multicolumn{10}{|c|}{ Порядковий номер модельного розчину (зразок, №) } \\
\hline & Контроль & 1 & 2 & 3 & 4 & 5 & 6 & 7 & 8 & 9 \\
\hline & \multicolumn{10}{|c|}{ Масова частка компоненту у розчині, \% } \\
\hline Молоко знежирене & 85,0 & 99,0 & 91,5 & 88,25 & 99,0 & 91,5 & 88,25 & 99,0 & 91,5 & 88,25 \\
\hline Казеїнат натрію & 15,0 & - & 7,5 & 10,75 & - & 7,5 & 10,75 & - & 7,5 & 10,75 \\
\hline Гуарова камедь & - & 1,0 & 1,0 & 1,0 & - & - & - & - & - & - \\
\hline Камедь ксантану & - & - & - & - & 1,0 & 1,0 & 1,0 & - & - & - \\
\hline Камедь рожкового дерева & - & - & - & - & - & - & - & 1,0 & 1,0 & 1,0 \\
\hline Всього & 100 & 100 & 100 & 100 & 100 & 100 & 100 & 100 & 100 & 100 \\
\hline
\end{tabular}

На першому етапі для приготованих модельних зразків досліджували залежність дотичного напруження зсуву від градієнта напруження на зріз. Покази віскозиметра фіксували на кожному етапі кроку швидкості, після витримки протягом 15 с. Визначення проводили при збільшенні швидкості обертання циліндра. На максимальній швидкості обертання систему витримували 60 с 3 подальшою фіксацією напруги зсуву. Отримані дані наведені на рисунках 1-3.

Аналізуючи отримані результати, можна зробити висновок, що полісахариди у взятій для досліджень кількості утворювали слабкоструктуровані системи, показник дотичного напруження на зріз підвищувався iз збільшенням градієнта напруження. Причому, значення дотичного напруження на зріз для зразків на основі камеді рожкового дерева виявилися вищими порівняно із зразками на основі камеді ксантану на 2,6\%, на основі гуарової камеді - на 1,3\%.
При введенні до системи КН у кількості 7,5\% (що складає 50,0\% від кількості КН у контрольному зразку) показник граничного напруження на зріз зростав в середньому для 2-го зразка - у 1,5 рази; для 5-го зразка - у 1,45 рази, для 8-го зразка - у 1,4 рази. Відповідно при введенні КН 10,25\% (що складає 75,0\% від кількості КН у контрольному зразку) показник граничного напруження на зріз суттєво зростав, у порівнянні із аналогічним показником для зразків із масовою часткою введення КН 7,5\%, - в середньому для 3-го зразка - у 9,2 рази; для 6-го зразка у 7,7 раз, для 9-го зразка - у 14 разів. Встановлено, що показник граничного напруження на зріз для зразків 3, 6 та 9 (масова частка КН 10,25\%) також виявився вищим, ніж для контрольного зразку, відповідно для 3-го зразка - у 8,8 разів; для 6-го зразка - у 8,8 разів, для 9го зразка - у 8,5 разів. 


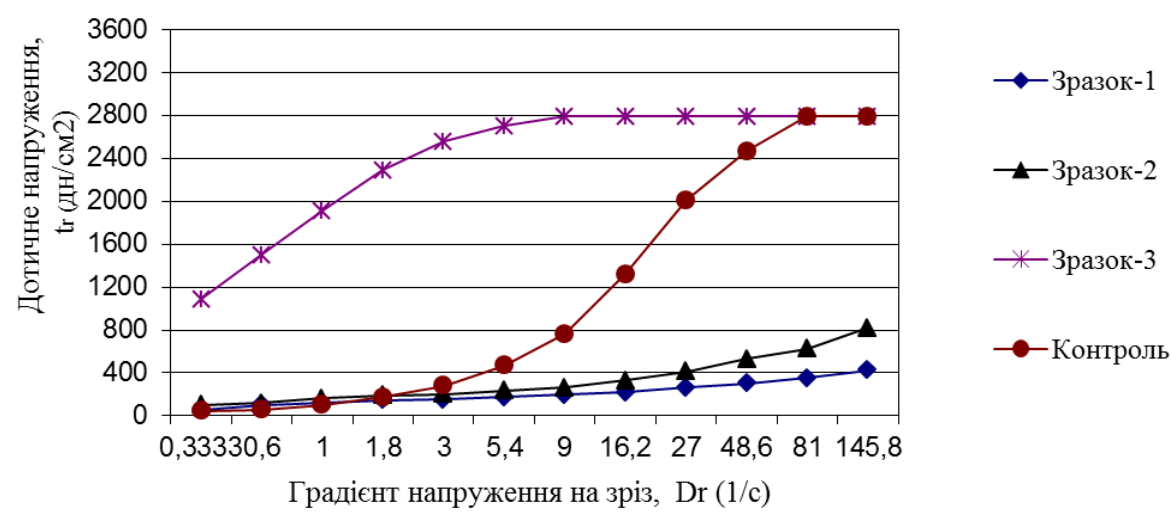

Рис.1. Залежність дотичного напруження від градіснту напруження на зріз модельних розчинів казеїнату натрію та БПК з ксантановою камеддю

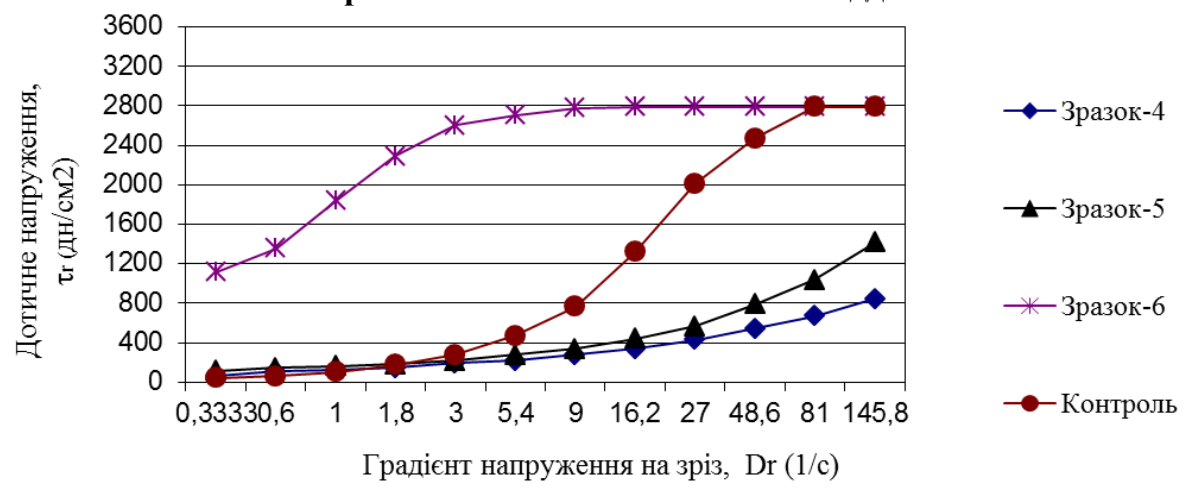

Рис. 2. Залежність дотичного напруження від градієнту напруження на зріз модельних розчинів казеїнату натрію та БПК з гуаровою камеддю

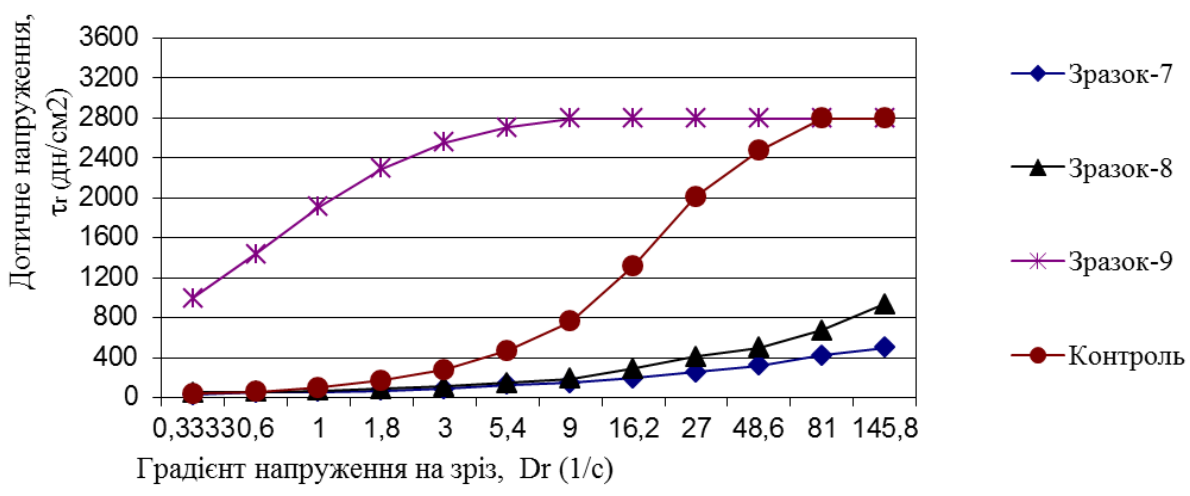

Рис.3. Залежність дотичного напруження від градіснту напруження на зріз модельних розчинів казеїнату натрію та БПК $з$ камеддю рожкового дерева

Значне підвищення показника граничного напруження на зсув у зразках із сумісним використанням КН та полісахаридів свідчить про ефект функціонального синергізму внаслідок комплексоутворення між вищезазначеними компонентами. Таким чином, для введення до складу масляних паст було взято зразки № 2, 3, 5, 6, 8, 9, що містили БПК.

На другому етапі нами було виготовлено та досліджено органолептичні показники та дисперсність водної фази модельних зразків масляних паст із масовою часткою жиру $45,0 \%$ на основі вищезазначених розчинів (контроль - масляна паста, виготовлена на основі РКН 15,0\% та масло вершкове з масовою часткою жиру 72,5\%). Оскільки масляна паста - це продукт із високим вмістом водної фази (45\%), тому здатність забезпечити високий ступінь дисперсності плазми є принциповим критерієм у рекомендації фо- рмування якісно-кількісного співвідношення у БПК. Результати досліджень дисперсності масляних паст 3 різними розчинами БПК наведено на рис.4.

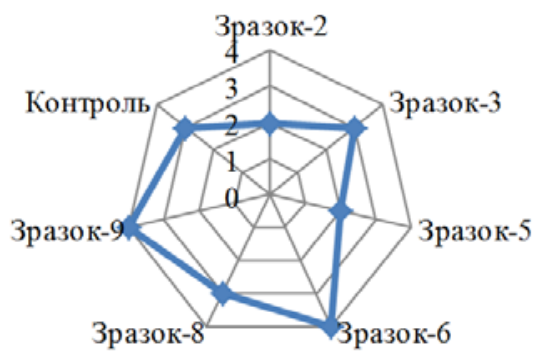

Рис. 4. Профілі оцінки дисперсності плазми (клас) виготовлених зразків масляних паст із різними модельними розчинами БПК 
Відповідно до рисунку 4 найвищу оцінку отримали зразки 3,6 та 9 масляної пасти, що містили камедь гуару та камедь плодів рожкового дерева, масова частка КН у яких була знижена на $25 \%$ відносно до контрольного зразку. Зразки масляних паст характеризувались чистим вершковим, солодкуватим смаком та запахом, без сторонніх присмаків та запахів. Зов- нішній вигляд і консистенція - однорідна, пластична, поверхня на зрізі суха на вигляд, блискуча, без видимих краплин вологи Колір - світло-жовтий, рівномірно розподілений за всією масою. Результати досліджень термостійкості масляних пасти порівняно 3 маслом вершковим 3 мчж 72,5\%. Результати досліджень наведено на рисунку 5.

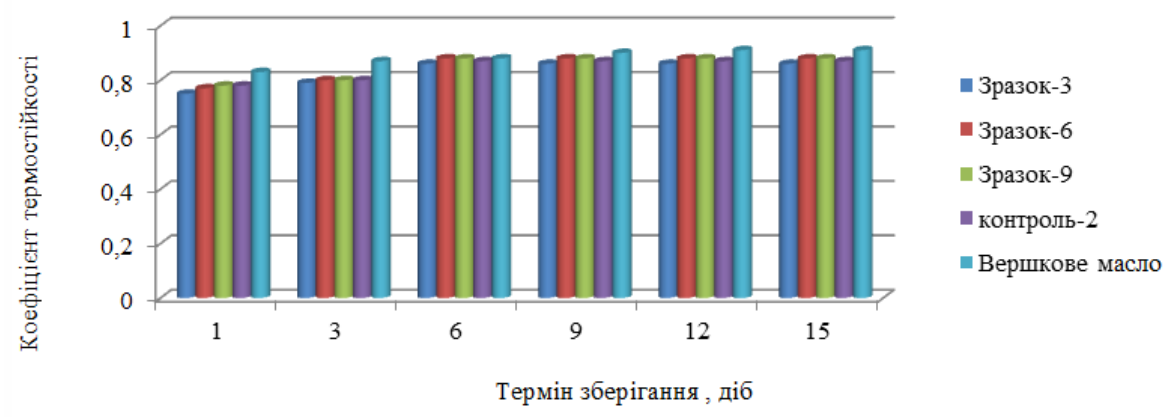

Рис. 5. Зміна термостійкості дослідних зразків масляних паст з БПК у процесі зберігання

Термостійкість дослідних зразків після 6-ї доби набуває сталих значень, що вказує на завершення процесів формування структури. Коефіцієнт термостійкості масляних паст майже збігається зі значенням відповідного показника вершкового масла і на 6-у добу знаходився в межах 0,86-0,88, що відповідає оцінці «добре». Отримані дані свідчать про ефективність використання БПК, що дає можливість досягти високих показників термостійкості для продукту.

\section{Висновки}

Доведено можливість створення ефективних білково-полісахаридних комплексів шляхом поєднання КН та камедей гуара, ксантана та плодів рожкового дерева. Це дозволить знизити дозу введення КН на $25,0 \%$ від початкової та отримати масляні пасти із органолептичними та структурно-механічними показниками, наближеними до традиційного вершкового масла. Часткове зниження кількості КН у рецептурі МП шляхом розробки БПК позитивно позначиться на собівартості продукту.

Перспективи подальших досліджень. Отримані результати будуть покладені в основу створення БПК із залученням ширшого спектру цільових функціонально-технологічних інгредієнтів.

\section{Бібліографічні посилання}

Imeson, A. (2010). Food Stabilisers, Thickeners and Gelling Agents Wiley-Blackwell.

Graveland-Bikker, J.F., de Kruif, C.G. (2006). Unique milk protein based nanotubes: Food and nanotechnology meet. Trends Food Sci Technol. 17, 196-203.

Derkach, S.R., Kukushkina, A.N., Levachov, S.M., Matveenko, V.N. (2012). The role of the cationic surfactants in concentrated emulsions stabilized with globular protein. Progress in Colloid and Polymer Sci. (in press).

Topnikova, E.V. (2006). Rol' jemul'gatorov i stabilizatorov $\mathrm{V}$ masloobrazovanii i formirovanii struktury masla ponizhennoj zhirnosti. Syrodelie i maslodelie. 5, 35-37 (in Russian).

Kosoj, V.D., Dunchenko, N.I., Merkulov, M.Ju. (2010). Reologija molochnyh produktov (polnyj kurs): uchebnik. M.: DeLiPrint (in Russian).

Стаття надійшла до редакиії 1.03.2017 